\title{
ANALISIS DAMPAK REMUNERASI DAN LINGKUNGAN KERJA TERHADAP KINERJA DOKTER SPESIALIS DENGAN MOTIVASI KERJA SEBAGAI VARIABEL MEDIASI
}

\author{
Hartati $^{1}$, Rima Semiarty ${ }^{2}$, Verinita ${ }^{3}$ \\ Universitas Andalas
}

\section{hartatifkm@gmail.com}

\begin{abstract}
Performance specialists is something that is very important in order to achieve the objectives Hospital Organization for specialists is the frontline in the service of clients in the hospital so important to know the factors that influence it. The purpose of this study is to describe the impact / influence of the system of remuneration and working environment on the performance and motivation as an intervening or mediating variable in the installation department of obstetrics and child XYZ Hospital Padang. This study uses a quantitative approach to research explanatori. Sampling in the Census, ie as many as 36 people obstetricians and children. Data analysis technique used in this study using the approach Partial Least Square (PLS).The results showed that there was no significant effect between remuneration and the performance of the T statistics amounted to 0.549 (less than 1.96) and the p value 0.002 (greater than 0.05) so the hypothesis is rejected. No significant difference between the work environment and performance statisticsT is smaller than TTable and $p$ value is greater than alpha so the hypothesis is rejected. No significant difference between the motivation to work on performance because the hypothesis is rejected. A significant difference between the remuneration and motivation to work as much as $2.8 \%$. No significant difference between the working environment on work motivation for the hypothesis is rejected. While remuneration on performance mediated by labor motivation does not have a significant effect.
\end{abstract}

Keywords: Remuneration, Working Environment, Motivation, Performance Specialist

\begin{abstract}
ABSTRAK
Kinerja Dokter spesialis merupakan suatu hal yang sangat penting dalam upaya Rumah Sakit untuk mencapai tujuan Organisasi karena dokter spesialis merupakan garda terdepan dalam pelayanan pada klien di Rumah sakit sehingga perlu diketahui faktor -faktor yang mempengaruhinya. Tujuan dari penelitian ini adalah untuk mengetahui gambaran dampak/ pengaruh system remunerasi dan lingkungan kerja terhadap kinerja dan motivasi kerja sebagai variabel intervening atau mediasi di instalasi kebidanan dan anak RSXYZ Padang. Penelitian ini menggunakan pendekatan kuantitatif yang bersifat explanatori research. Pengambilan Sampel secara Sensus, yakni sebanyak 36 orang dokter spesialis kebidanan dan anak. Sedangkan teknik analisis data yang digunakan dalam penelitian ini menggunakan pendekatan Partial Least Square (PLS). PLS adalah model persamaan Structural Equation Modeling (SEM) yang berbasis komponen atau varian. Hasil penelitian menunjukkan bahwa tidak terdapat pengaruh yang signifikan antara remunerasi dan terhadap kinerja $\mathrm{T}$ statistics sebesar 0,549 (lebih kecil dari 1,96) dan p value 0,002 (lebih besar dari 0,05) sehingga Hipotesis ditolak. Tidak terdapat pengaruh yang signifikan antara lingkungan kerja dan kinerja $\mathrm{T}$ statistics lebih kecil dari Ttable dan pvalue lebih besar dari alpha sehingga hipotesis ditolak. Tidak terdapat pengaruh yang signifikan antara motivasi kerja terhadap kinerja karena hipotesis ditolak. Terdapat pengaruh yang signifikan antara remunerasi dan motivasi kerja sebanyak 2,8\%. Tidak terdapat pengaruh yang signifikan antara lingkungan kerja terhadap motivasi kerja karena hipotesis ditolak. Sedangkan remunerasi terhadap kinerja yang dimediasi oleh motivasi kerja tidak memiliki pengaruh yang signifikan. Dan lingkungan kerja terhadap kinerja yang dimediasi oleh motivasi kerja juga tidak memiliki pengaruh yang signifikan.
\end{abstract}

Kata Kunci: Sistem Remunerasi, Lingkungan Kerja, Motivasi, Kinerja Dokter Spesialis 


\section{Terakreditasi Nasional}

\section{PENDAHULUAN}

Pemerintah sekaligus komitmen pemerintah untuk mewujudkan clean and good governance. Perubahan dan pembaharuan yang dilaksanakan dalam rangka mewujudkan tata pemerintahan yang bersih dan berwibawa tidak mungkin akan dapat dilaksanakan dengan baik (efektif) tanpa kesejahteraan yang layak dari Pegawai Negeri Sipil (PNS) sebagai pelaksana tugas pemerintahan. Perubahan dan pembaharuan tersebut dilaksanakan untuk menghapus kesan pemerintahan yang selama ini dinilai buruk. (Tarigan, 2011)

Program remunerasi menjadi bagian dari program penataan sistem dengan kegiatan analisis jabatan, evaluasi jabatan dan sistem remunerasi. Analisis jabatan ditujukan untuk menilai beban kerja dengan evaluasi sebagai monitornya dan sistem remunerasi merupakan kompensasi dari penataan sistem beban kerja. Artinya, tidak ada remunerasi tanpa beban kerja, karena remunerasi diberikan berdasarkan bobot beban kerja yang ditetapkan melalui penentuan nilai dan kelas jabatan (analisis jabatan). Remunerasi atau kompensasi dapat mempengaruhi motivasi pegawai sekaligus meningkatkan kinerjanya. Hal ini disebabkan oleh pemberian remunerasi yang baik dapat memberikan daya tarik pegawai untuk bekerja lebih baik. Kompensasi atau imbalan akan berpengaruh untuk meningkatkan motivasi kerja yang pada akhirnya secara langsung akan meningkatkan kinerja individu (Angliawati, 2016).

Lingkungan kerja yang kondusif memberikan rasa aman dan memungkinkan karyawan untuk bekerja secara optimal. Jika karyawan menyenangi lingkungan kerja dimana dia bekerja, maka karyawan tersebut akan betah ditempat kerjanya, melakukan aktifitasnya sehingga waktu kerja dikerjakan dipergunakan secara efektif, sebaliknya lingkungan kerja yang tidak memadai akan dapat menurunkan kinerja karyawan (Nuraini, 2013,p.97). Lingkungan kerja merupakan keadaan sekitar tempat kerja baik secara fisik maupun non fisik yang dapat memberikan kesan menyenangkan, mengamankan, menentramkan, dan kesan betah bekerja dan lain sebagainya (Supardi, 2003, p.37). Didukung dengan pengertian lingkungan kerja diatas (Indra Gunawan Manaf dkk. 2015) menegaskan pula bahwa secara garis besar lingkungan kerja terbagi menjadi 2 yaitu : 1) lingkungan kerja fisik,dan 2) lingkungan kerja non fisik.

Menurut Hasibuan (2012), motivasi adalah pemberian daya penggerak yang menciptakan kegairahan seseorang agar mereka mau bekerja sama, bekerja efektif dan terintegrasi dengan segala daya upayanya untuk mencapai kepuasaan.

Motivasi mempersoalkan bagaimana caranya mengarahkan daya dan potensi bawahannya, agar mau bekerja sama secara produktif berhasil mencapai tujuan yang telah ditentukan. Salah satu tujuan pemberian kompensasi adalah motivasi. apabila balas jasa yang diberikan lumayan besar, maka seorang manajer akan lebih ringan memotivasi bawahannya. Motivasi kerja merupakan suatu modal dalam menggerakkan dan mengarahkan para karyawan atau pekerja agar dapat melaksanakan tugasnya masing-masing dalam mencapai sasaran dengan penuh kesadaran, kegairahan, dan bertanggung jawab (Hasibuan, 2008).

Manajemen kinerja berkaitan dengan usaha, kegiatan atau program yang diprakarsai dan dilaksanakan oleh pimpinan organisasi untuk merencanakan mengarahkan dan mengendalikan prestasi karyawan. Manajemen kinerja pada dasarnya adalah sebuah proses dalam manajemen sumber daya manusia, dalam program manajemen tersebut mempunyai implikasi bahwa kegiatan tersebut harus dilaksanakan sebagai sebuah proses manajemen yang umum yang dimulai dengan penetapan tujuan dan sasaran, dan diakhiri dengan evaluasi. (Mangkunegara, 2012)

Remunerasi Khusus dalam hal jasa medis di RSXYZ Padang merupakan besaran nilai jumlah uang yang diterima oleh tenaga medis sebagai kompensasi atas kinerja yang telah dilakukan, berkaitan dengan risiko dan tanggung jawab profesi dari pekerjaannya, bahwa layanan rumah sakit merupakan hasil dari satu kerjasama berbagai unit/layanan bersama, dengan berbagai proporsi, kerja, risiko dan tanggung jawab. Untuk sistem remunerasi dokter di rumah sakit dihitung berdasarkan profesional grade, penetapan Indikator Kinerja Individu (IKI) dan Indikator Kinerja Unit (IKU).

Berdasarkan hasil survey awal penelitian dengan telaah dokumen laporan kinerja bidang pelayanan medik tahun 2018 didapatkan data meningkatnya jumlah angka kematian di IGD 


\section{Terakreditasi Nasional}

\section{Available Online at: http://ejournal.upbatam.ac.id/index.php/jim}

sebesar $2,5 \%$, tingginya angka kematian ibu $>3 \%$ dari standar $0 \%$ yang ditetapkan, sedangkan kematian bayi $>2,5 \%$ dari $2,5 \%$ standar yang ditetapkan, serta meningkatnya jumlah angka kematian di instasi rawat inap ambun pagi sebesar 2,5\% selama tahun 2019 . Angka tersebut didapatkan dari data laporan pertahun. Capaian kinerja unit tersebut tidak terlepas dari andil kinerja staf medis fungsional (SMF).

Dampak dari implementasi remunerasi akan berpengaruh terhadap kinerja dokter spesialis yang ada diinstalasi kebidanan anak berdasarkan faktor motivasi kerja, lingkungan kerja, sehingga dari faktor - faktor tersebut akan berdampak pada pelayanan di instalasi kebidanan dan anak RSXYZ Padang. Berdasarkan uraian diatas, peneliti tertarik untuk mengadakan penelitian mengenai analisis dampak remunerasi dan lingkungan kerja terhadap kinerja dokter spesialis dengan motivasi kerja sebagai variabel mediasi di instalasi kebidanan dan anak RS XYZ Padang.

\section{TINJAUAN PUSTAKA}

\section{Sistem Remunerasi}

Kata remunerasi menurut Oxford advance learner's dictionary of current english (AS Hornby) Remuneration adalah Payment atau Reward berarti pembayaran, penghargaan , imbalan yang mana istilah imbalan sering juga dalam bahasa Indonesia digunakan istilah kompensasi. Berbagai buku-buku manajemen sumber daya manusia yang banyak beredar di Indonesia terutama buku yang merupakan terjemahan yang berasal dari Amerika menggunakan istilah kompensasi untuk mengungkapkan hal tersebut. Namun Bangsa Inggris maupun Organisasi Buruh International (International Labour Organization/ILO) menyebutnya dengan istilah Remuneration.

Remunerasi merupakan suatu aspek yang penting bagi karyawan maupun rumah sakit. Adapun pengertian remunerasi menurut para ahli dan beberapa literatur adalah sebagai berikut :

1. Remunerasi adalah pengeluaran biaya oleh Badan Layanan Umum Rumah Sakit, sebagai imbal jasa kepada pegawai yang manfaatnya diterima pegawai dalam bentuk dan jenis komponen-komponen penghargaan dan perlindungan (Kepmenkes No 625/2010).
2. Menurut Surya (2004) dalam Angliawati (2016) menyebutkan bahwa remunerasi adalah berupa sesuatu yang diterima pegawai sebagai imbalan dari kontribusi yang telah diberikannya kepada organisasi tempat bekerja

3. Remunerasi dalam kamus besar bahasa Indonesia kata remunerasi diartikan sebagai pemberian hadiah, penghargaan atas jasa dan sebagainya.

4. Remunerasi jasa medis adalah besaran nilai jumlah uang yang harus diterima oleh tenaga medis sebagai kompensasi atas kinerja yang dilakukan berkaitan dengan resiko dan tanggung jawab profesi dari pekerjaannya (Sanjani, 2014).

5. Remunerasi adalah merupakan imbalan atau balas jasa yang diberikan kepada tenaga kerja sebagai akibat dari prestasi yang telah diberikannya dalam rangka mencapai tujuan organisasi (Sofa, 2008 dalam Isyandi,2014). Menurut Milkovich and Newman (2002) dalam Sancoko (2010)“Compensation refers to all forms of financial return and tangible service and benefits employee receive as part an employement relationship".

Akibat adanya ketidakpuasan dalam pembayaran dapat mengurangi kinerja, meningkatkan keluhan - keluhan, serta menyebabkan pegawai mogok kerja. Sebaliknya jika terjadi kelebihan pembayaran akan menyebabkan perusahaan dan individual berkurang daya kompetisinya sehingga menyebabkan kegelisahaan, dan ketidaknyaman. Faktor yang mempengaruhi remunerasi Menurut Jensen dan Meckling (1976), berasal dari luar perusahaan (external equity, internal equity, individual equity).

Salah satu upaya untuk memotivasi dan meningkatkan kinerja pegawai adalah melalui remunerasi. Bila sistem remunerasi disusun secara adil, benar, dan wajar, maka para pegawai akan meraas puas dan termotivasi untuk mencapai sasaran dan tujuan organisasi. Tingkat remunerasi karyawan akan menentukan skala kehidupan serta akan menunjukkan martabat dan status sosial di masyarakat. Oleh karena itu bila karyawan menganggap bahwa remunerasi yang mereka terima kurang memadai maka kepuasan kinerja mereka menurun, tidak termotivasi dan akhirnya akan berpengaruh terhadap 


\section{Terakreditasi Nasional}

\section{Available Online at: http://ejournal.upbatam.ac.id/index.php/jim}

kinerja pegawai, sehingga mutu pelayanan dan capaian organisasi tidak tercapai.

Remunerasi dalam Permendagri No. 61 Tahun 2007 tentang pedoman teknis pengelolaan keuangan badan layanan umum daerah secara garis besar sama seperti permenkeu No. 10 Tahun 2006 yaitu imbalan kerja yang berupa gaji, honorium, tunjangan tetap, insentif, bonus, atau prestasi, dan atau pensiun yang diberikan sesuai dengan tingkat tanggungjawab dan tuntutan profesionalisme pegawai.

Kompenen remunerasi atau pengupahan di Rumah Sakit biasanya terdiri dari gaji pokok, berbagai tunjangan, dan insentif pelayanan. Dari komponen - komponen ini pembagian insentif jasa pelayanan sering menjadi masalah karena tidak terpenuhinya aspek keadilan. Kelompok pemberi layanan harus mendapatkan porsi yang lebih besar karena mereka sebagai revenue center sedangkan kelompok administrasi dan penunjang merasa walaupun mereka merupakan cost center tetapi tanpa mereka pelayanan tidak akan optimal. Sistem remunerasi harus dapat menjamin kesejahteraan pegawai tetapi juga bukan beban berat keuangan (Tangkas, 2011).

\section{Manajamen Kinerja}

Manajemen kinerja pada dasarnya merupakan sebuah program dalam manajemen sumber daya manusia. Selain itu penggunaan istilah "manajemen" dalam nama program tersebut mempunyai implikasi bahwa kegiatan tersebut harus dilaksanakan sebagai proses manajemen yang mulai dengan penetapan tujuan dan sasaran, dan diakhiri dengan evaluasi. Proses tersebut pada garis besarnya terdiri dari lima kegiatan utama yaitu:

1. Merumuskan tanggungjawab dan tugas yang harus dicapai oleh seseorang karyawan dan rumusan tersebut disepakati oleh atasan dari karyawan tersebut. Langkah perumusan tersebut mencakup kegiatan menetapkan dalam hal atau bidang apa saja seseorang dituntut untuk memberikan kontribusi berupa hasil.

2. Menyepakati sasaran kerja dalam bentuk hasil yang harus dicapai oleh karyawan untuk kurun waktu tertentu. Termasuk dalam tahap ini adalah penetepan standar prestasi dan tolak ukurnya.
3. Melakukan "monitoring", melakukan koreksi, memberikan kesempatan dan bantuan yang diperlukan oleh karyawan

4. Menilai prestasi karyawan tersebut dengan cara membandingkan prestasi yang dicapai (actual) dengan standar atau tolak ukur yang telah ditetapkan dalam langkah pertama. Dalam tahap penilaian ini harus tercakup pula kegiatan mengindentifikasi bidang - bidang yang ada dirasakan terdapat kelemahan pada orang yang dinilai.

Memberikan umpan balik kepada karyawan yang dinilai tentang seluruh hasil penilaian yang dilakukan. Dalam proses pemberian umpan balik ini atasan dan bawahan membicarakan cara - cara untuk memperbaiki kelemahan yang telah diketahui dengan tujuan meningkatkan prestasi pada periode berikutnya Indikator kinerja adalah ukuran kuantitatif atau kualitatif yang menggambarkan tingkat pencapaian suatu sasaran atau tujuan yang telah ditetapkan (BPKP dalam Abdullah, 2014:145). Sementara itu menurut Lohman (2003) dalam Abdullah (2014:145) indikator kinerja adalah suatu variabel yang digunakan untuk mengekspresikan secara kuantitatif efektivitas dan efisinesi proses atau operasi dengan berpedoman pada target-target dan tujuan organisasi. Dalam pandangan lain, Moeheriono (2012:108) mendefinisikan indikator kinerja sebagai berikut:

a. Indikator kinerja adalah nilai atau karakteristik tertentu yang digunakan untuk mengukur ouput atau outcome suatu kegiatan.

b. Indikator kinerja adalah alat ukur yang dipergunakan untuk menentukan derajat keberhasilan suatu organisasi dalam mencapai tujuannya.

Untuk mengetahui tingkat keberhasilan yang dicapai pegawai maka perlu adanya pengukuran kinerja seperti yang dikemukakan oleh Dharma (2004:24) bahwa hampir semua pengukuran kinerja mempertimbangkan halhal sebagai berikut:

1) Kuantitas, berkaitan dengan jumlah yang harus diselesaikan atau dicapai.

2) Kualitas, berkaitan dengan mutu yang dihasilkan baik berupa kerapian kerja dan ketelitian kerja atau tingkat kesalahan yang dilakukan pegawai. 


\section{Terakreditasi Nasional}

\section{Available Online at: http://ejournal.upbatam.ac.id/index.php/jim}

3) Ketepatan waktu, yaitu sesuai apa tidak dengan waktu yang direncanakan.

\section{Motivasi Kerja}

Istilah motivasi (motivation) berasal dari kata bahasa latin, yaitu" movere" yang berarti menggerakkan (to move). Kata dasar motivasi adalah" motive' yang berarti dorongan, sebab atau alasan seseorang melakukan sesuatu (Winardi, 2001). Pengertian motivasi Menurut Robert Heller menyatakan bahwa motivasi adalah keinginan untuk bertindak. Motivasi merupakan proses psikologis yang membangkitkan dan mengarahkan perilaku pada pencapaian tujuan atau goal directed behavior.

Menurut Stepen P. Robbins motivasi sebagai proses yang menyebabkan intensitas, arah dan usaha terus-menerus individu menuju pencapaian tujuan.

Jerald Greenberg dan Robert A. Baron mengatakan motivasi merupakan serangkaian proses yang membangkitkan, mengarahkan dan menjaga perilaku manusia menuju pada pencapaian tujuan. (Wibowo, 2013:378-379). Pengertian Motivasi kerja menurut Uno (2008) merupakan salah satu faktor yang menentukan kinerja seseorang, besar atau kecilnya pengaruh motivasi pada kinerja seseorang tergantung pada seberapa banyak intensitas motivasi yang diberikan.

Menurut Uno (2008) bahwa secara implisit motivasi kerja tampak melalui tanggung jawab dalam melakukan kerja, prestasi yang dicapainya, pengembangan diri,serta kemandirian dalam bertindak. Keempat hal tersebut merupakan indikator penting untuk menelusuri motivasi kerja.

Teori Motivasi kerja menurut Mc Clelland berfokus pada tiga kebutuhan

a) Achievement (kebutuhan akan prestasi) dorongan untuk mengungguli, berprestasi sehubungan dengan seperangkat standar,bergulat untuk sukses.

b) Power (kebutuhan akan kekuasaan) merupakan kebutuhan untuk membuat orang lain berprilaku dalam suatu cara yang orang-orang itu (tanpa dipaksa) tidak akan berprilaku demikian.

c) Affiliation (kebutuhan akan pertalian) yaitu hasrat untuk hubungan antar pribadi yang ramah dan karib (Mc Clelland).

Mc Clelland mengemukakan 6 karakteristik orang yang mempunyai motif berprestasi tinggi dalam motivasi kerja yaitu sebagai berikut:

a) Memiliki tingkat tanggung jawab pribadi yang tinggi

b) Berani mengambil dan memikul resiko

c) Memiliki rencana kerja yang menyeluruh dan berjuang untuk merealisasikan tujuan.

d) Memanfaatkan umpan balik yang kongkrit dalam semua rencana kegiatan yang dilakukan.

e) Mencari kesempatan untuk merealisasikan rencana yang telah diprogramkan.

Mc Clelland menjelaskan tentang karakteristik motivasi kerja yang tinggi dan karakteristik motivasi kerja yang rendah disini tampak dijelaskan bahwa dengan karakteristik pegawai yang mempunyai motivasi kerja yang rendah akan berdampak pada pegawai itu sendiri yaitu:

a) Kurangnya memiliki tanggung jawab pribadi dalam mengerjakan sesuatu pekerjaan atau kegiatan.

b) Memiliki program kerja tetapi tidak didasarkan pada rencana dan tujuan yang realistis, serta lemah melaksanakannya.

c) Bersikap apatis dan kurang percaya diri.

d) Ragu-ragu dalam mengambil keputusan.

e) Tindakannya kurang terarah pada tujuan.

Jenis-Jenis Motivasi Kerja Menurut Fahmi (2013) Motivasi dapat dibedakan menjadi dua jenis yaitu:

1. Motivasi Instrinsik

Motivasi yang berfungsi tanpa membutuhkan adanya rangsangan dari luar. Seseorang melakukan sesuatu karena rasa senang. Motivasi instrinsik lahir secara alamiah pada diri individu (internal) tanpa dipengaruhi oleh pengaruh luar. Dalam hal ini pujian atau hadiah dan sejenisnya tidak diperlukan karena tidak akan menyebabkan seseorang bertindak lantaran mendapatkan pujian atau hadiah tersebut.

2. Motivasi Ekstrinsik

Motivasi yang berfungsi karena adanya rangsangan dari luar individu. Seseorang berbuat sesuatu karena dorongan dari luar, seperti adanya hadiah, menghindari hukuman, adanya penghargaan, pujian dan lainnya yang berasal dari luar (eksternal) diri individu tersebut. Pada saat ini motivasi ekstrinsik banyak dilakukan dilembaga atau masyarakat 


\section{Terakreditasi Nasional}

\section{Available Online at: http://ejournal.upbatam.ac.id/index.php/jim}

seperti pemberian hadiah, insentif atau penghargaan terhadap suatu prestasi kerja.

Menurut Hasibuan (2012) jenis motivasi yaitu :

1. Motivasi Positif (Intensif Positif)

Manajer memotivasi bawahan dengan memberikan hadiah kepada mereka yang berprestasi diatas prestasi standar.

2. Motivasi Negatif (Intensif Negatif)

Manajer memotivasi bawahan dengan standar mereka akan mendapatkan hukuman.

\section{Lingkungan Kerja}

Lingkungan kerja dalam suatu perusahaan sangat penting untuk diperhatikan oleh pihak manajemen. Meskipun lingkungan kerja tidak melaksanakan proses produksi dalam suatu perusahaan, namun lingkungan kerja mempunyai pengaruh langsung terhadap para karyawan yang melaksanakan proses produksi tersebut. Lingkungan kerja adalah suasana dimana karyawan melakukan aktivitas setiap harinya.

Lingkungan kerja yang kondusif memberikan rasa aman dan memungkinkan karyawan untuk bekerja secara optimal. Jika karyawan menyenangi lingkungan kerja dimana dia bekerja, maka karyawan tersebut akan betah ditempat kerjanya, melakukan aktifitasnya sehingga waktu kerja dikerjakan dipergunakan secara efektif . sebaliknya lingkungan kerja yang tidak memadai akan dapat menurunkan kinerja karyawan. Beberapa ahli mendefinisikan lingkungan kerja antara lain sebagai berikut:

Menurut (Nitisemito dalam Nuraini 2013:97) lingkungan kerja adalah segala sesuatu yang ada disekitar karyawan dan mempengaruhi dalam menjalan tugas yang diembankan kepadanya misalnya dengan adanya Air Conditioner (AC), penerangan yang memadai dan sebagainya.

Menurut (Simanjutak, 2010) lingkungan kerja dapat diartikan sebagai keseluruhan alat perkakas yang dihadapi , lingkungan sekitarnya dimana seorang bekerja, metode kerjanya, sebagai pengaruh kerja yang baik sebagai perorangan maupun kelompok. Aspek Lingkungan Kerja Lingkungan kerja dapat dibagi menjadi beberapa bagian atau bisa disebut juga aspek pembentuk lingkungan kerja, bagian - bagian itu bisa diuraikan sebagai berikut (Simajuntak, 2013):
1.Pelayanan kerja

Pelayanan karyawan merupakan aspek terpenting yang harus dilakukan oleh setiap perusahaan terhadap kerja. Pelayanan yang baik dari perusahaan akan membuat karyawan lebih bergairah dalam bekerja, mempunyai rasa tanggungjawab dalam menyelesaikan pekerjaannya, serta dapat terus menjaga nama baik perusahaan melalui produktivitas kerjanya dan tingkah lakunya. Pada umumnya pelayanan karyawan meliputi beberapa hal:

a) Pelayanan makanan dan minuman

b) Pelayanan kesehatan

c) Pelayanan fasilitas kerja

\section{Kondisi kerja}

Kondisi kerja sebaiknya diusahakan oleh manajemen organisasi sebaik mungkin agar timbul rasa aman dalam bekerja untuk karyawannya, kondisi kerja ini meliputi penerangan yang cukup, suhu udara yang tepat, kebisingan yang dapat dikendalikan, pengaruh warna ruang gerak yang diperlukan dan keamanan kerja karyawan.

3.Hubungan karyawan

Hubungan karyawan akan sangat menentukan dalam menghasilkan produktivitas kerja. Hal ini disebabkan karena adanya hubungan antara motivasi serta semangat dan kegairahan kerja dengan hubungan yang kondusif antar sesama karyawan dalam bekerja, ketidakserasian hubungan antara karyawan dan menurunkan motivasi kerja yang akan mengakibatkan menurunnya produktivitas kerja.

\section{Rumah Sakit}

Rumah Sakit merupakan pusat pelayanan rujukan medik spesialistik dan subspesialistik, dengan fungsi utama menyediakan dan menyelenggakan upaya kesehatan yang bersifat penyembuhan (kuratif) dan pemulihan (rehabilitatif) pasien (Depkes RI 1989). Menurut Undang-undang No. 44 Tahun 2009, tugas rumah sakit umum adalah memberikan pelayanan kesehatan perorangan secara paripurna (Ilyas, 2001).

Rumah sakit adalah sarana kesehatan yang menyelenggarakan pelayanan kesehatan perorangan meliputi pelayanan promotif, preventif, kuratif, dan rehabilitatif yang menyediakan pelayanan rawat inap, rawat jalan, dan gawat darurat (SPM, 2008). Rumah Sakit menurut Wolper dan Pena merupakan tempat dimana orang sakit mencari dan 


\section{Terakreditasi Nasional}

\section{Available Online at: http://ejournal.upbatam.ac.id/index.php/jim}

menerima pelayanan kedokteran serta tempat pendidikan klinik. Rumah Sakit menurut Association of Hospital Care adalah pusat terselenggaranya pelayanan kesehatan masyarakat, pendidikan, serta penelitian kedokteran. (Azwar, 2010).

Klasifikasi Pelayanan Rumah Sakit, jenisjenis pelayanan kesehatan di rumah sakit, antara lain (Susatyo, 2016):

1. Administrasi dan Manajemen

Di rumah sakit jajaran administrasi disebut dengan jajaran struktural, yang menjalankan tugas pokok dan fungsinya di bidang administrasi dan manajerial, seperti administrasi dan manajemen pasien rawat jalan dan rawat inap, administrasi dan manajemen akuntasi keuangan, administrasi dan manajemen sumber daya manusia, administrasi dan manajemen pemasaran.

2. Pelayanan Medis

Pelayanan medis di rumah sakit yaitu menjadikan seorang penderita suatu penyakit keluar dari rumah sakit dengan

\section{Kerangka Konsep}

Kerangka konsep dalam penelitian ini ditarik dari teori yang dijelaskan dari tinjauan pustaka dan penelitian sebelumnya yang telah dijelaskan dalam telaah jurnal penelitian sebelumnya.

\section{Variabel Independen}

\section{Variabel Dependen}

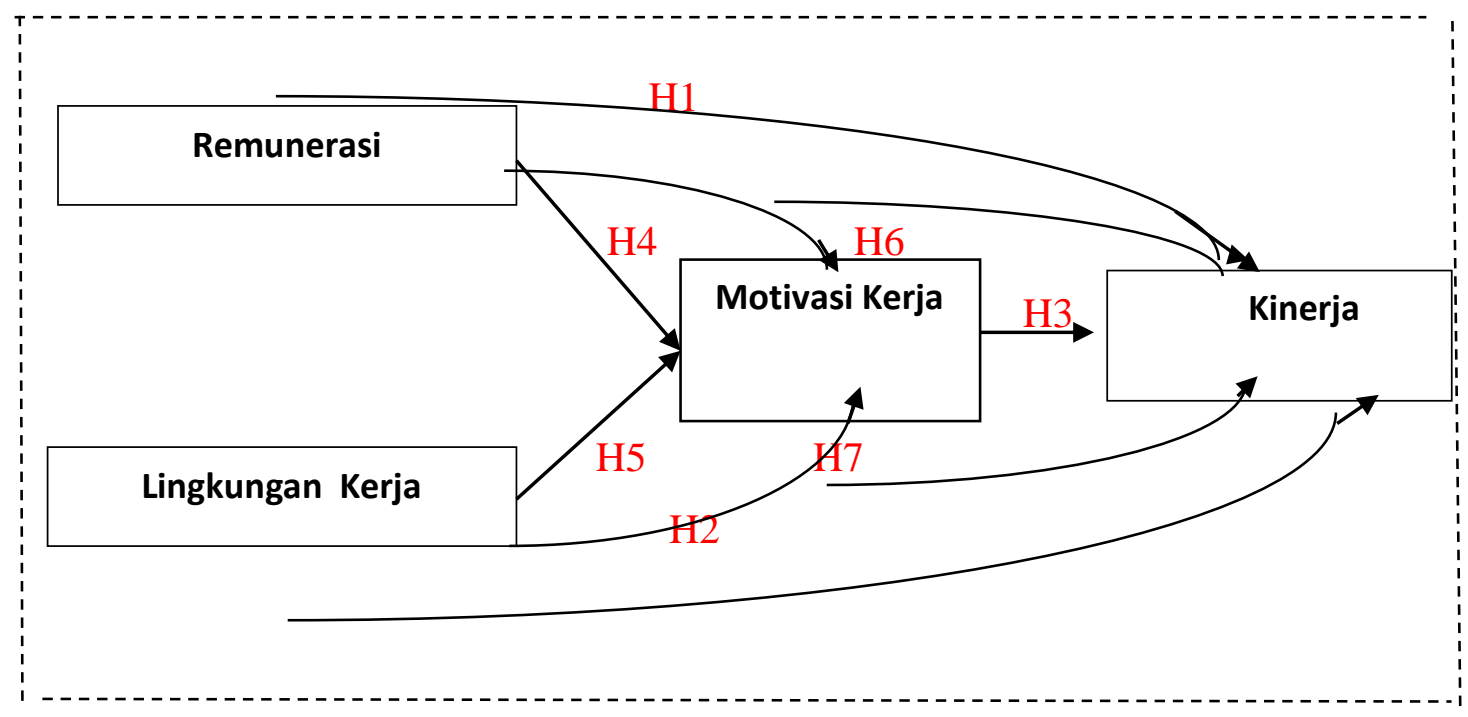

Gambar. 1 Kerangka Konsep

$\mathrm{H1}:$ Remunerasi berpengaruh dan signifikan terhadap kinerja

H2:Lingkungan kerja berpengaruh dan signifikan terhadap kinerja

H3:Motivasi Kerja berpengaruh dan signifikan terhadap kinerja sehat dan bukan sebaliknya. Pelayanan medis antara lain : Bedah, kesehatan anak, kebidanan dan penyakit kandungan, penyakit dalam, penyakit mata, penyakit syaraf, penyakit kulit dan kelamin, THT, gigi dan mulut, radiologi, patologi anatomi, patologi klinik, kedokteran kehakiman, dan rehabilitasi medik.

3. Pelayanan Gawat Darurat

Pelayanan Gawat Darurat atau Instalasi Gawat Darurat (IGD) adalah bentuk pelayanan medis sebuah rumah sakit yang berkaitan dengan kegawat daruratan, seperti persalinan, kecelakaan, dan berbagai bentuk pelayanan yang memerlukan tindakan cepat, tepat, dan akurat untuk menyelamatkan pasien.

4. Pelayanan Keperawatan

Pelayanan keperawatan diberikan oleh rumah sakit khususnya untuk pasien rumah sakit yang memerlukan pelayanan medis rawat inap maupun rawat jalan, serta membutuhkan bantuan tenaga keperawatan dalam rangka penyembuhan 


\section{Terakreditasi Nasional}

\section{Available Online at: http://ejournal.upbatam.ac.id/index.php/jim}

H7:Lingkungan Kerja berpengaruh dan signifikan terhadap kinerja dimediasi oleh motivasi kerja.

\section{METODE}

Desain Penelitian ini berupa explanatory research. Explanatory research yaitu penelitian yang digunakan untuk menjelaskan hubungan kausal antara variabel-variabel melalui pengujian hipotesa yang dirumuskan atau sering kali disebut sebagai penelitian penjelas dengan pendekatan kuantitatif (Singarimbun \& Effendi, 2006). Penelitian ini untuk melihat pengaruh satu dimensi dengan dimensi yang lain atau variabel dengan variabel yang lain dengan pendekatan kuantitatif. Dalam hal ini, melihat dampak remunerasi dan lingkungan kerja terhadap kinerja dokter spesialis dengan motivasi kerja sebagai variabel mediasi di Instalasi Kebidanan dan Anak RSXYZ Padang

Analisis data dalam penelitian ini menggunakan pendekatan Partial Least Square (PLS). PLS adalah model persamaan Structural Equation Modeling (SEM) yang berbasis komponen atau varian. Menurut Ghozali (2013) tujuan PLS adalah membantu peneliti untuk tujuan prediksi. Model formalnya mendefinisikan variabel laten adalah linear agregat dari indikatorindikatornya. Weight estimate untuk menciptakan komponen skor variabel laten didapat berdasarkan bagaimana outer model (model pengukuran yaitu hubungan antara indikator dengan konstruknya) dan inner model (model struktural yang menghubungkan antar variabel laten).

\section{Model Pengukuran}

Analisa Outer Model ini menspesifikasi hubungan antar variabel laten dengan indikator-indikatornya atau dapat dikatakan bahwa outer model mendefinisikan bagaimana setiap indikator berhubungan dengan variabel latennya. Uji yang dilakukan pada outer model (Ghozali, 2013):

a. Convergent Validity. Nilai convergent validity adalah nilai loading faktor pada variabel laten dengan indikatorindikatornya. Nilai yang diharapkan $>0.7$.

b. Composite Reliability. Data yang memiliki composite reliability $>0.7$ mempunyi reliabilitas yang tinggi. c. Average Variance Extracted (AVE). nilai ini menggambarkan validitas konvergen yang memadai yang mempunyai arti bahwa suatu variabel laten (variabel independen dan dependen) mampu menjelaskan lebih dari setengah varian dari indikatornya dalam rata-rata. Nilai AVE yang diharapkan $>0.5$.

d. Cronbach Alpha. Uji reliabilitas diperkuat dengan Cronbach Alpha. Nilai diharapkan $>0.7$ untuk semua konstruk.

2. Model Struktural

Inner model menggambarkan hubungan antara variabel laten berdasarkan pada teori substantif. Model struktural dievaluasi dengan menggunakan $R$ square untuk konstruk dependen. Dalam menilai model dengan PLS dimulai dengan melihat $R$-square untuk setiap variabel laten dependen yaitu variabel kinerja. Perubahan nilai $R$-square dapat digunakan untuk menilai pengaruh variabel laten independen (remunerasi, motivasi kerja) terhadap variabel laten dependen (variabel kinerja) apakah mempunyai pengaruh yang substantif (Ghozali, 2013).

A. $R$-square dikategorikan kuat jika nilai $R$-square sebesar $>0,7$

B. $R$-square dikategorikan substansial jika nilai $R$-square sebesar 0,67

C. $R$-square dikategorikan Moderate jika nilai $R$-square sebesar 0,33

D. $R$-square dikategorikan lemah jika nilai $R$-square sebesar 0,19

3. Pengujian Hipotesis

Untuk pengujian hipotesis digunakan nilai $\alpha$-statistics $5 \%$ dimana nilai $t_{\text {table }}{ }^{-}$ statistics yang digunakan adalah 1,96. Suatu hipotesis atau Ha diterima apabila $\mathrm{t}_{\text {hitung }}{ }^{- \text {statistics }}>1,96$ dan $\mathrm{P}$ value $<0,05$. Sebaliknya suatu hipotesis atau $\mathrm{Ha}$ ditolak apabila $t_{\text {hitung }}$-s statistics $<1,96$ dan $\mathrm{P}$ value $>0,05$.

\section{HASIL DAN PEMBAHASAN \\ Hasil \\ Karakteristik Responden}

Berdasarkan penelitian yang telah dilakukan terhadap \pm 40 orang dokter spesialis kebidanan dan anak, diperoleh informasi mengenai karakteristik responden yang terdiri 


\section{Terakreditasi Nasional}

Available Online at: http://ejournal.upbatam.ac.id/index.php/jim

dari umur, jenis kelamin, lama bekerja, status tanggungnan. Rekapitulasinya dapat dilihat karyawan, status pernikahan, dan jumlah pada tabel 9.

Tabel.9.Karakteristik Responden

\begin{tabular}{llll}
\hline Variabel & Karakteristik & $\begin{array}{l}\text { Frekuensi } \\
\text { (Orang) }\end{array}$ & $\begin{array}{l}\text { Persentase } \\
(\%)\end{array}$ \\
\hline \multirow{4}{*}{ Umur } & $20-24$ tahun & & 0 \\
& $25-35$ tahun & 2 & 5.5 \\
& $>35$ tahun & 34 & 94.5 \\
\cline { 2 - 4 } Jenis Kelamin & Lumlah & $\mathbf{3 6}$ & $\mathbf{1 0 0}$ \\
& Perempuan & 14 & 38.8 \\
& Jumlah & 22 & 61.1 \\
\hline \multirow{4}{*}{ Lama Kerja } & $0-5$ tahun & $\mathbf{3 6}$ & $\mathbf{1 0 0}$ \\
& 6-10 tahun & 1 & 2.7 \\
& $>10$ tahun & 6 & 16.2 \\
\cline { 2 - 4 } Status Kepegawaian & 30 & 81.0 \\
\cline { 2 - 4 } & Jumlah & $\mathbf{3 6}$ & $\mathbf{1 0 0}$ \\
\hline \multirow{3}{*}{ Pendidikan Terakhir } & PNS Kemenkes & 16 & 44.4 \\
& PNS Dikti & 20 & 55.5 \\
\cline { 2 - 4 } & Jumlah & $\mathbf{3 6}$ & $\mathbf{1 0 0}$ \\
\hline & Spesialis & 2 & 5.5 \\
\cline { 2 - 4 } & Subspesialis & 34 & 94.4 \\
\cline { 2 - 4 } & Jumlah & $\mathbf{3 6}$ & $\mathbf{1 0 0}$ \\
\hline
\end{tabular}

Sumber: Data primer yang diolah (2019)

Berdasarkan tabel. 9 distribusi frekuensi umur responden, mayoritas responden memiliki umur antara $>35$ tahun yaitu sebanyak 34 orang $(94,5 \%)$, sedangkan usia dibawah 35 tahun hanya 2 orang $(5,5 \%)$.

Berdasarkan distribusi frekuensi jenis kelamin, mayoritas responden adalah berjenis kelamin perempuan yaitu sebanyak 22 orang $(61,1 \%)$, sementara sisanya sebanyak 14 orang $(38,8 \%)$ adalah laki-laki. Disamping itu terdapat sebanyak 30 orang $(81 \%)$ responden dengan kategori masa lama bekerja $>10$ tahun, dan sebanyak 6 orang $(16,2 \%)$ responden dengan kategori masa lama kerja antara 6-10 tahun, sementara 1 orang $(2,7 \%)$ dengan masa kerja berkisar 0-5 tahun.

Berdasarkan distribusi frekuensi status kepegawaian, kebanyakan responden merupakan berstatus PNS Dikti yaitu sebanyak 20 orang $(55,5 \%)$, kemudian disusul dengan status kepegawaian PNS Kemenkes sebanyak 16 orang $(44,4 \%)$.Karekteristik responden terakhir dibedakan atas Pendidikan terakhir dokter spesialis, dimana berdasarkan kategori ini, kebanyakan responden adalah dokter subspesialis sebanyak 34 orang $(94,4 \%)$, sedangkan yang masih dokter spesialis sebanyak 2 orang $(5,5 \%)$

\section{Analisis Outer Model}

Analisa outer model berguna untuk mengetahui hubungan antara variabel laten dengan indikator-indikatornya. Uji yang dilakukan pada outer model adalah composite reliability, dan cronbach alpha (Ghozali, 2013).

\section{Analisis Realibilitas}

Data yang memiliki composite reliability $>0.7$ mempunyai reliabilitas yang tinggi. Dengan demikian dalam penelitian ini setiap variabel harus memiliki composite reliability lebih besar dari 0.7. Hasil analisis composite reliability dapat dilihat sebagai berikut:

Tabel. 10 Hasil Analisis Reliabilitas

\begin{tabular}{llll}
\hline Variabel & $\begin{array}{l}\text { Composite } \\
\text { Reliability }\end{array}$ & $\begin{array}{l}\text { Nilai } \\
\text { Cut- } \\
\text { off }\end{array}$ & Keputusan \\
\hline Remunerasi & 0.878 & 0.7 & Reliabel \\
$\begin{array}{l}\text { Motivasi } \\
\text { Kerja }\end{array}$ & 0.847 & 0.7 & Reliabel \\
$\begin{array}{l}\text { Lingkungan } \\
\text { Kerja }\end{array}$ & 0.727 & 0.7 & Reliabel \\
Remunerasi & 0.878 & 0.7 & Reliabel \\
\hline
\end{tabular}

Sumber: Data primer yang diolah (2018) 


\section{Terakreditasi Nasional}

\section{Available Online at: http://ejournal.upbatam.ac.id/index.php/jim}

Berdasarkan tabel diatas dapat dilihat bahwa variabel remunerasi memiliki composite reliablity sebesar 0.878 , motivasi kerja 0.847, lingkungan kerja 0.727 dan remunerasi 0.878. Dengan demikian dapat disimpulkan bahwa semua variabel penelitian memiliki composite reliability lebih besar dari nilai batas yang ditetapkan (cut-off) yaitu 0.7 , sehingga dapat diartikan bahwa semua variabel penlitian adalah reliabel atau andal.

\section{Cronbach Alpha}

Cronbach alpha merupakan alat statistik yang digunakan untuk mengetahui kehandalan variabel. Suatu variabel diakatakan andal apabila memiliki nilai cronbach alpha lebih besar atau sama dengan 0.7 (Sekaran, 2006). Hasil analisis cronbach alpha dapat dilihat sebagai berikut.

Tabel. 11 Hasil Analisis Cronbach Alpha

\begin{tabular}{llll}
\hline Variabel & $\begin{array}{l}\text { Cronbach } \\
\text { Alpha }\end{array}$ & $\begin{array}{l}\text { Nilai } \\
\text { Cut- } \\
\text { off }\end{array}$ & Keputusan \\
\hline Remunerasi & 0.841 & 0.7 & Andal \\
$\begin{array}{l}\text { Motivasi } \\
\text { Kerja }\end{array}$ & 0.792 & 0.7 & Andal \\
$\begin{array}{l}\text { Lingkungan } \\
\text { Kerja }\end{array}$ & 0.644 & 0.7 & $\begin{array}{l}\text { Tidak } \\
\text { Kinerja }\end{array}$ \\
\hline
\end{tabular}

Sumber: Data primer yang diolah (2018).

Hasil analisis cronbach alpha pada tabel 4.8 diatas menunjukkan bahwa variabel remunerasi memiliki cronbach alpha sebesar 0.841 , motivasi kerja 0.792 , lingkungan kerja 0.644 dan kinerja 0.794. Dengan demikian dapat disimpulkan bahwa hampir semua variabel penelitian memiliki nilai cronbach alpha lebih besar dari nilai batas yang ditetapkan (cut-off) yaitu 0.7, namun varaibel lingkungan kerja memiliki nilai cronbach alpha 0.644, sehingga dapat diartikan bahwa semua variabel penelitian dinyatakan andal
Model struktural (Inner Model)

Inner model menggambarkan hubungan antara variabel laten berdasarkan pada teori substantif. Model struktural dievaluasi dengan menggunakan $R$-square untuk konstruk dependen. Dalam penelitian ini kegunaan $R$ square adalah a) untuk mengetahui besarnya pengaruh remunerasi dan lingkungan terhadap motivasi kerja; dan b) untuk mengetahui besarnya pengaruh remunerasi, lingkungan dan motivasi terhadap kinerja.

Tabel 16. Hasil $R$ Square

\begin{tabular}{|c|c|c|c|}
\hline $\begin{array}{l}\mathbf{N} \\
\mathbf{0}\end{array}$ & Variabel & $\begin{array}{l}\mathbf{R} \\
\text { Squar } \\
e\end{array}$ & $\begin{array}{l}\mathbf{R} \text { Square } \\
\text { Adjusted }\end{array}$ \\
\hline 1 & $\begin{array}{l}\text { Motivasi } \\
\text { Kerja }\end{array}$ & 0,507 & 0,477 \\
\hline 2 & Kinerja & 0,269 & 0,200 \\
\hline
\end{tabular}

Berdasarkan tabel 16 diatas dapat dilihat bahwa variabel motivasi kerja memiliki $\mathrm{R}$ Square 0,507 dan R Square Adjusted 0,477. Temuan ini bermakna bahwa besarnya pengaruh remunerasi dan lingkungan terhadap motivasi kerja pada Dokter Spesialis Kebidanan dan Anak di RSXYZ Padang adalah 50,7 \%, sementara sisanya $49.3 \%$ dipengaruhi oleh variabel lain yang tidak termasuk kedalam ruang lingkup penelitian ini.Variabel kinerja memiliki koefisien $\mathrm{R}$ Square sebesar 0,269 dan R Square Adjusted 0,200 . Temuan ini bermakna bahwa besarnya pengaruh remunerasi, lingkungan dan motivasi terhadap kinerja pada Dokter Spesialis Kebidanan dan Anak di RSXYZ Padang adalah $26,9 \%$, sementara sisanya 20,0 \% dipengaruhi oleh variabel lain yang tidak termasuk kedalam ruang lingkup penelitian ini.

Pengujian hipotesis menggunakan analisis Partial Least Square (PLS) dimana secara full model dapat dilhat pada gambar berikut: 
Available Online at: http://ejournal.upbatam.ac.id/index.php/jim

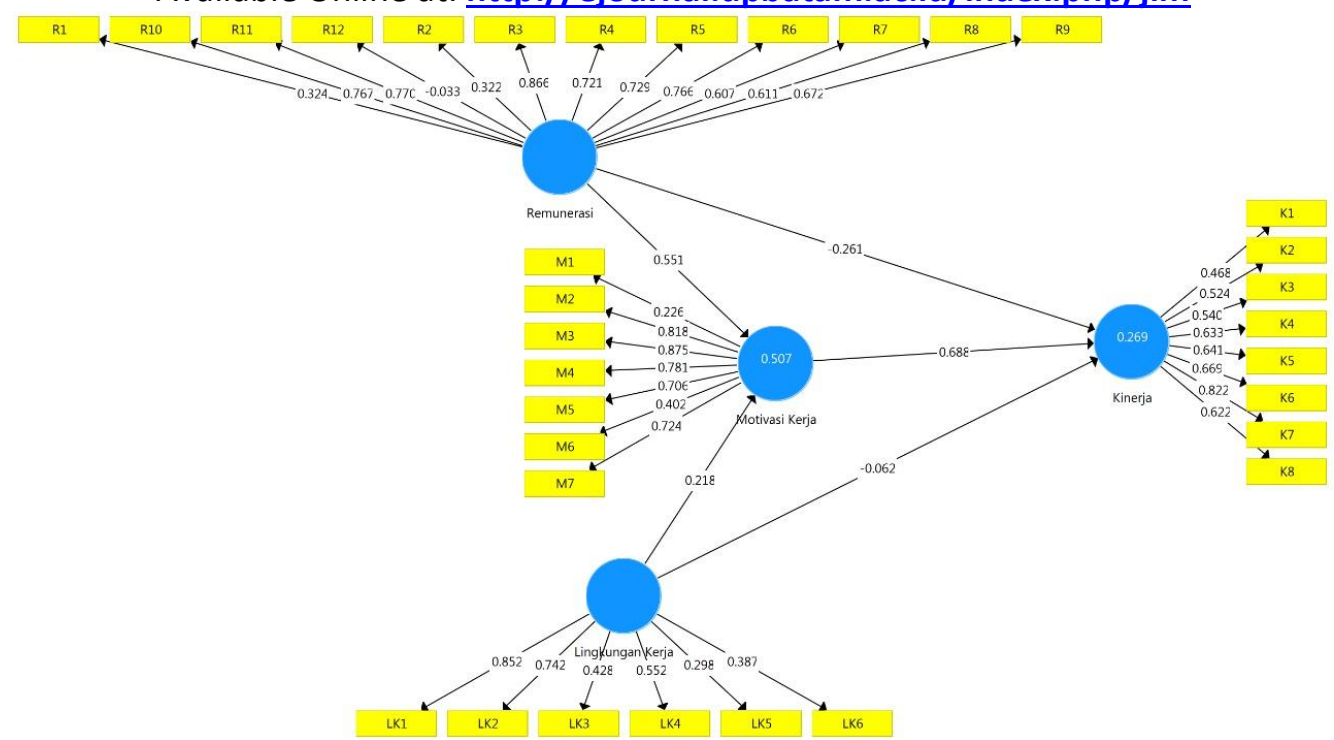

Gambar 3. Model Hasil Pengujian Hipotesis dengan Smart-PLS

Gambar 3 diatas menunjukkan hasil pengujian hipotesis penelitian dimana dalam model tersebut variabel remunerasi (12 item), motivasi kerja (7 item), lingkungan kerja (6 item) dan kinerja (8 item). Hasil pengujian hipotesis selain ditampilkan seperti pada Gambar 3 dapat diringkas dalam bentuk tabel seperti berikut.

Tabel 17. Hasil Uji Hipotesis

\begin{tabular}{lllll}
\hline Arah Pengaruh & $\begin{array}{l}\text { Koefisien } \\
\text { Jalur }\end{array}$ & $\begin{array}{l}\text { T } \\
\text { Statistics }\end{array}$ & $\begin{array}{l}\text { P } \\
\text { Values }\end{array}$ & Keputusan \\
\hline Direct Effect & & & & \\
\hline Remunerasi $\rightarrow$ Kinerja & 0,261 & 0,549 & 0,583 & $\mathrm{H}_{1}$ ditolak \\
\hline Lingkungan Kerja $\rightarrow$ Kinerja & 0,062 & 0,130 & 0,897 & $\mathrm{H}_{2}$ ditolak \\
\hline Motivasi Kerja $\rightarrow$ Kinerja & 0,688 & 1,787 & 0.074 & $\mathrm{H}_{3}$ ditolak \\
\hline Remunerasi $\rightarrow$ Motivasi Kerja & 0,551 & 2,831 & 0.005 & $\mathrm{H}_{4}$ diterima \\
\hline Lingkungan Kerja $\rightarrow$ Motivasi Kerja & 0,218 & 1,153 & 0.250 & $\mathrm{H}_{5}$ ditolak \\
\hline Indirect Effect & & & & \\
\hline Remunerasi $\rightarrow$ Motivasi Kerja $\rightarrow$ Kinerja & 0,379 & 1,324 & 0.186 & $\mathrm{H}_{6}$ ditolak \\
\hline $\begin{array}{l}\text { Lingkungan Kerja } \rightarrow \text { Motivasi Kerja } \rightarrow \\
\text { Kinerja }\end{array}$ & 0,150 & 1,102 & 0.271 & $\mathrm{H}_{7}$ ditolak \\
\hline
\end{tabular}

Sumber: Data primer yang diolah (2019)

Berdasarkan hasil pengujian hipótesis yang diringkas pada Tabel 15 dapat dijelaskan sebagai berikut:

1. Pengaruh Remunerasi terhadap kinerja memiliki koefisien jalur sebesar 0,261 dan T statistics sebesar 0,549 (lebih kecil dari 1.96) dan $\mathrm{P}$ value 0.002 (lebih besar dari 0.05). Dengan demikian dapat disimpulkan bahwa remunerasi tidak berpengaruh dan tidak signifikan terhadap kinerja pada Dokter Spesialis Kebidanan dan Anak RSXYZ Padang, sehingga hipótesis pertama $\left(\mathrm{H}_{1}\right)$ dapat ditolak.

2. Pengaruh lingkungan kerja terhadap kinerja memiliki koefisien jalur sebesar 0,62 dan T statistics sebesar 0,130 (lebih kecil dari 1.96) dan $\mathrm{P}$ value 0.005 (lebih besar dari 0.05). Dengan demikian dapat disimpulkan bahwa lingkungan kerja tidak berpangaruh secara signifikan terhadap kinerja pada Dokter Spesialis Kebidanan dan Anak RSUP RSXYZ Padang, sehingga hipótesis kedua $\left(\mathrm{H}_{2}\right)$ dapat ditolak.

3. Pengaruh motivasi kerja terhadap kinerja memiliki koefisien jalur sebesar 0,688 dan T statistics sebesar 1,787 (lebih kecil dari 1.96) dan P value 0.074 (lebih besar dari 0.05). Dengan demikian dapat disimpulkan bahwa motivasi kerja tidak berpangaruh secara signifikan terhadap kinerja pada Dokter Spesialis Kebidanan 


\section{Terakreditasi Nasional}

\section{Available Online at: http://ejournal.upbatam.ac.id/index.php/jim}

dan Anak RSXYZ Padang, sehingga hipótesis kedua $\left(\mathrm{H}_{3}\right)$ dapat ditolak.

4. Pengaruh Remunerasi terhadap motivasi kerja memiliki koefisien jalur sebesar 0,551 dan T statistics sebesar 2,831 (lebih besar dari 1.96) dan P value 0.005 (lebih kecil dari 0.05). Dengan demikian dapat disimpulkan bahwa remunerasi berpangaruh secara signifikan terhadap motivasi kerja pada Dokter Spesialis Kebidanan dan Anak RSXYZ Padang, sehingga hipótesis kedua $\left(\mathrm{H}_{4}\right)$ dapat diterima.

5. Pengaruh lingkungan kerja terhadap motivasi kerja memiliki koefisien jalur sebesar 0,218 dan $\mathrm{T}$ statistics sebesar 1,153 (lebih kecil dari 1.96) dan $\mathrm{P}$ value 0,250 (lebih besar dari 0.05). Dengan demikian dapat disimpulkan bahwa lingkungan kerja tidak berpangaruh secara signifikan terhadap motivasi kerja pada Dokter Spesialis Kebidanan dan Anak RSXYZ Padang, sehingga hipótesis kedua $\left(\mathrm{H}_{5}\right)$ dapat ditolak.

6. Pengaruh remunerasi terhadap kinerja yang dimediasi oleh motivasi memiliki koefisien jalur sebesar 0,379 dan $\mathrm{T}$ statistics sebesar 1,324 (lebih kecil dari 1.96) dan $\mathrm{P}$ value 0,186 (lebih besar dari 0.05). Dengan demikian dapat disimpulkan bahwa remunerasi tidak berpangaruh terhadap kinerja yang dimediasi oleh motivasi kerja pada Dokter Spesialis Kebidanan dan Anak RSXYZ Padang, sehingga hipótesis keenam $\left(\mathrm{H}_{6}\right)$ dapat ditolak.

7. Pengaruh lingkungan kerja terhadap kinerja yang dimediasi oleh motivasi memiliki koefisien jalur sebesar 0,150 dan T statistics sebesar 1,102 (lebih kecil dari 1.96) dan P value 0,271 (lebih besar dari 0.05). Dengan demikian dapat disimpulkan bahwa lingkungan kerja terhadap kinerja yang dimediasi oleh motivasi pada Dokter Spesialis Kebidanan dan Anak RSXYZ Padang, sehingga hipótesis keenam $\left(\mathrm{H}_{7}\right)$ dapat ditolak.

\section{Pembahasan}

\section{Pengaruh Langsung}

\section{Pengaruh Remunerasi terhadap Kinerja}

Hipotesa pertama $(\mathrm{H} 1)$ pada penelitian ini adalah ada pengaruh remunerasi terhadap kinerja dokter kebidanan dan anak RSUP Dr.M.Djamil Padang. Hasil pengujian hipotesa pertama memperlihatkan tidak adanya hubungan yang signifikan antara variable remunerasi dengan kinerja. Hal ini bermakna bahwa jika remunerasi yang diberikan tinggi tidak akan berpengaruh terhadap kinerja dokter spesialis kebidanan dan anak RSUP Dr.M.Djamil Padang, dan sebaliknya jika remunerasi rendah juga tidak akan berpengaruh terhadap kinerja dokter spesialis kebidanan dan anak RSXYZ Padang.

Secara empiris penelitian ini tidak sejalan dengan penelitian oleh (Kristina,2015), Pengaruh Remunerasi pegawai terhadap kinerja pegawai di kementerian sekretariat negara Republik, hasil penelitian menunjukkan bahwa Remunerasi memiliki pengaruh terhadap kinerja. Sedangkan penelitian lain dilakukan oleh (Dian, 2018), tentang pengaruh remunerasi, lingkungan kerja dan kompetensi terhadap kinerja pegawai, menemukan bahwa remunerasi berpengaruh dan signifikan terhadap kinerja.

Dari penelitian ini dapat disimpulkan bahwa variable remunerasi tidak mempengaruhi kinerja dokter spesialis kebidanan dan anak RSXYZ Padang. Seharusnya dengan penerapan sistem remunerasi yang baik akan meningkatkan kinerja dokter spesialis, namun jika sistem remunerasi yang dijalankan tidak baik maka akan menurunkan kinerja dokter spesialis, tetapi berdasarkan penelitian ini hipotesa 1 ditolak, artinya penerapan remunerasi tidak berpengaruh dalam peningkatan kinerja dokter spesialis kebidanan dan anak RSXYZ Padang. Adanya pengaruh lain yang mempengaruhi kinerja dokter spesialis kebidanan dan anak RSXYZ Padang yang tidak termasuk dalam lingkup penelitian ini. Untuk memperkuat hasil penelitian ini, peneliti melakukan wawancara dengan dokter spesialis, bahwa penerapan remunerasi saat ini masih belum berasaskan keterbukaan, dan tepat waktu, sehingga kepercayaan dokter spesialis terhadap pemberian remunerasi sangat rendah. Jika manajemen sudah menerapkan sistem remunerasi yang transparansi, akuntabel yang sesuai dengan penilai indiator kinerja yang terukur maka akan lebih meningkatkan kinerja dokter spesialis dalam memberian pelayanan 


\section{Pengaruh Lingkungan Kerja Terhadap Kinerja}

Available Online at: http://ejournal.upbatam.ac.id/index.php/jim

Hipotesa kedua $(\mathrm{H} 2)$ pada penelitian ini adalah ada pengaruh lingkungan kerja terhadap kinerja dokter spesialis kebidanan dan anak RSXYZ Padang. Hasil pengujian hipotesa kedua memperlihatkan tidak adanya hubungan yang signifikan antara variable lingkungan kerja dengan kinerja dokter spesialis kebidanan dan anak RSXYZ Padang. Hal ini menunjukkan bahwa lingkungan kerja yang kondusif tidak mampu mendukung pekerjaan yang dibebankan pada dokter spesialis dan tidak dapat mempengaruhi kinerja dokter spesialis itu sendiri.

Secara empiris penelitian ini tidak sejalan dengan beberapa penelitian terdahulu, penelitian yang dilakukan oleh yayat hidayat (2016) tentang Pengaruh Sistem Remunerasi dan Lingkungan Kerja Terhadap Motivasi Kerja dan Dampaknya Terhadap Kinerja Perawat Di RS Paru DR. H.A Rotinsulu Bandung menunjukkan bahwa lingkungan kerja dapat berpengaruh terhadap kinerja.

Begitu juga dengan penelitian oleh Rodi A. (2013), tentang Pengaruh lingkungan kerja terhadap kinerja karyawan pada dinas pendidikan, pemuda, dan olahraga sleman yogyakarta. Hasil penelitian menunjukkan bahwa adanya pengaruh lingkungan kerja terhadap kinerja pegawai. Dari penelitian ini dapat disimpulkan bahwa variabel lingkungan kerja tidak dapat mempengaruhi kinerja dokter spesialis kebidanan dan anak RSXYZ Padang. Penelitian ini didukung dengan hasil wawancara mendalam dengan dokter spesialis yang berpendapat bahwa lingkungan kerja saat ini dari aspek pelayanan kerja (pelayanan makanan minuman, fasilitas kesehatan) yang ada saat ini belum optimal untuk mendukung kinerja dokter spesialis. Sehingga tidak ada pengaruh yang signifikan terhadap peningkatan kinerja dokter spesialis kebidanan dan anak RSXYZ Padang

\section{Pengaruh Motivasi Kerja Terhadap Kinerja}

Hipotesa ketiga (H3) pada penelitian ini adalah ada pengaruh motivasi kerja terhadap kinerja dokter spesialis kebidanan dan anak RSXYZ Padang. Hasil pengujian hipotesa ketiga memperlihatkan tidak adanya hubungan yang signifikan antara variable motivasi kerja dengan kinerja dokter spesialis kebidanan dan anak RSXYZ Padang. Hal ini menunjukkan bahwa motivasi kerja dokter spesialis kebidanan dan anak RSXYZ Padang belum mampu mempengaruhi kinerja. Peningkatan motivasi pegawai ini merupakan hal yang sangat berarti bagi setiap organisasi, baik itu organisasi pemerintahan maupun organisasi di lingkungan perusahaan. Seorang pegawai yang mempunyai motivasi tinggi dalam bekerja akan memberikan yang terbaik bagi suatu organisasi.

Hal inilah yang menyebabkan motivasi sangat memberikan kontribusi yang penting bagi setiap organisasi. Prawirosentono (1999) mengatakan bahwa kinerja dipengaruhi oleh motivasi karyawan yang bekerja dalam suatu organisasi. Bila motivasi karyawan itu rendah, maka hasil kerja atau kinerjanya juga rendah. Dari penelitian ini dapat disimpulkan bahwa variable motivasi kerja tidak mempengaruhi kinerja dokter spesialis kebidanan dan anak RSXYZ Padang. Tingginya motivasi kerja dokter spesialis kebidanan anak belum dapat mempengaruhi peningkatan kinerja dokter spesialis tersebut, begitu juga sebaliknya. Seharusnya motivasi kerja dapat meningkatkan kinerja dokter spesialis, dengan memiliki motivasi kerja yang tinggi maka dokter spesialis dapat memberikan pelayanan terbaik terhadap pasien sehingga hal ini dapat meningkatkan kinerja dokter spesialis. Namun hal ini tidak terlepas dari sistem manajemen SDM yang diterapkan di RSXYZ Padang, yang mana dengan menerapkan sistem reward dan punishmen yang tegas terhadap dokter spesialis akan dapat memberikan motivasi terhadap dokter spesialis untuk meningkatkan kinerja yang diberikan terhadap pelayanan.

\section{Pengaruh Remunerasi Terhadap Motivasi Kerja}

Hipotesis keempat (H4) pada penelitian ini adalah pengaruh remunerasi terhadap motivasi kerja dokter spesialis kebidanan dan anak RSXYZ Padang. Hasil pengujian hipotesis keempat ini memperlihatkan hubungan positif antara variable remunerasi terhadap variable motivasi kerja dokter spesialis kebidanan dan anak RSXYZ Padang. Hal ini bermakna bahwa jika penerapan sistem remunerasi di RSXYZ Padang dilaksanakan dengan baik maka secara langsung dapat meningkatkan motivasi kerja dokter spesialis, namun sebaliknya jika penerapan sistem remunerasi di RSXYZ Padang tidak dapat diterapkan dengan baik maka hal ini dapat menyebabkan 
Available Online at: http://ejournal.upbatam.ac.id/index.php/jim

rendahnya motivasi kerja dokter spesialis kebidanan dan anak RSXYZ Padang dalam memberikan pelayanan yang terbaik di RSXYZ Padang.

Wildan alvian et al. (2017), motivasi kerja dapat meningkat maka konsistensi dosen dalam menjalankan tugas akan selalu terjaga. Harapan Universitas Brawijaya terhadap hasil kerja yang baik oleh dosen akan lebih mudah untuk dicapai, sehingga kualitas kerja dapat terjaga dan terus meningkat. Jika ditinjau dalam teori dua faktor terdapat keterkaitan antara kepuasan dan motivasi kerja yang mana keduanya menjadi unsur satu sama lain mempengaruhi, ketika faktor motivasi dalam teori tersebut berfungsi sebagai faktor yang memuaskan meliputi dorongan bekerja giat, memberikan pengakuan, bersifat tanggung jawab.

Dari penelitian ini, maka disimpulkan bahwa variable remunerasi mempengaruhi variabel motivasi kerja terhadap kinerja dokter spesialis kebidanan dan anak RSXYZ Padang. Dengan lebih baiknya pemberian remunerasi yang diterapkan oleh pihak manajemen RSXYZ Padang, maka secara langsung mempengaruhi tingginya motivasi kerja dokter spesialis kebidanan dan anak RSXYZ Padang. Jadi semakin baik penerapan dalam pembayaran sistem remunerasi kepada dokter spesialis kebidanan dan anak RSXYZ Padang, maka akan semakin tinggi motivasi kerja dalam memberikan pelayanan terhadap pasien oleh dokter spesialis.

\section{Pengaruh Lingkungan Kerja Terhadap Motivasi Kerja}

Hipotesis kelima (H5) pada penelitian ini adalah pengaruh lingkungan kerja terhadap motivasi kerja dokter spesialis kebidanan dan anak RSXYZ Padang. Hasil pengujian hipotesis kelima ini memperlihatkan tidak ada pengaruh yang signifikan antara variable lingkungan kerja terhadap variable motivasi kerja dokter spesialis kebidanan dan anak RSXYZ Padang. Hal ini bermakna bahwa jika lingkungan kerja yang ada saat ini di lingkungan instalasi kebidanan dan anak tidak mempengaruhi dalam meningkatkan motivasi kerja dokter spesialis kebidanan dan anak RSXYZ Padang. Secara empiris penelitian ini tidak sejalan dengan penelitian Yayat hidayat (2016), tentang Pengaruh Sistem Remunerasi dan Lingkungan Kerja Terhadap Motivasi Kerja dan Dampaknya Terhadap Kinerja
Perawat Di RS Paru DR. H.A Rotinsulu Bandung, menunjukkan bahwa semakin baik Lingkungan kerja maka berdampak pada Motivasi kerja yang semakin tinggi, sebaliknya semakin buruk lingkungan kerja maka berdampak pada motivasi kerja perawat yang semakin rendah.

Dari penelitian, maka dapat disimpulkan bahwa variabel lingkungan kerja tidak mempengaruhi motivasi kerja dokter spesialis kebidanan dan anak RSXYZ Padang. Suasana kerja di lingkungan kerja instalasi kebidanan dan anak tidak dapat mempengaruhi motivasi dokter spesialis dalam meningkatkan kinerja terhadap pelayanan di instalasi kebidanan dan anak. Hal ini bisa disebabkan oleh factor suasana kerja, hubungan kerja, pelayanan kerja seperti pelayanan makanan dan minuman yang diberikan pihak manajemen terhadap dokter spesialis saat ini tidak ada perubahan dengan yang sebelumnya, sehingga tidak begitu mendorong motivasi kerja dokter spesialis kebidanan dan anak dalam memberikan pelayanan terbaik.

\section{Pengaruh Tidak Langsung}

\section{Pengaruh Remunerasi Terhadap Kinerja Yang di Mediasi Oleh Motivasi Kerja \\ Hasil pengujian hipotesis keenam (H6)} diketahui bahwa variabel motivasi kerja berperan sebagai variabel mediasi antara remunerasi dan kinerja dokter spesialis kebidanan dan anak RSXYZ Padang. Hasil penelitian ini menunjukkan tidak adanya pengaruh yang signifikan antara remunerasi terhadap kinerja dimediasi oleh motivasi kerja. Hal ini bermakna bahwa penerapan remunerasi yang diberikan oleh pihak manajemen rumah sakit belum mampu meningkatkan kinerja dokter spesialis kebidanan dan anak RSXYZ Padang, walaupun sudah dimediasi oleh faktor motivasi kerja. Secara empiris, hasil penelitian ini tidak didukung oleh hasil penelitian terdahulu, yang menunjukkan hasil bahwa remunerasi seharusnya berpengaruh yang positif dan signifikan terhadap kinerja dan variable motivasi sebagai variable intervening (yayat hidayat, 2016) .

Dari penelitian ini, maka dapat disimpulkan bahwa variabel remunerasi yang dimediasi oleh motivasi kerja tidak mempengaruhi kinerja terhadap dokter spesialis kebidanan dan anak RSXYZ Padang. Dengan lebih baiknya sistem remunerasi yang 


\section{Available Online at: http://ejournal.upbatam.ac.id/index.php/jim}

diterapkan oleh manajemen RSXYZ Padang maka akan memberikan efek positif terhadap motivasi kerja yang akan berdampak pada kinerja terhadap pelayanan yang diberikan oleh dokter spesialis kebidanan dan anak RSXYZ Padang, begitupun sebaliknya. Peningkatan motivasi kerja dan kinerja dokter spesialis terhadap penerapan sistem remunerasi merupakan hal penting bagi pihak manajemen dalam peningkatan mutu dan kinerja pelayanan di RSXYZ Padang.

\section{Pengaruh Lingkungan Kerja Terhadap Kinerja Yang di Mediasi Oleh Motivasi Kerja}

Hasil pengujian hipotesis ketujuh (H7) diketahui bahwa variabel motivasi kerja berperan sebagai variabel mediasi antara lingkungan kerja dan kinerja dokter spesialis kebidanan dan anak RSXYZ Padang. Hasil penelitian ini menunjukkan tidak adanya pengaruh yang signifikan antara lingkungan kerja terhadap kinerja dimediasi oleh motivasi kerja. Hal ini bermakna bahwa lingkungan kerja saat ini di lingkungan instalasi kebidanan dan anak RSXYZ Padang belum mampu meningkatkan kinerja dokter spesialis kebidanan dan anak RSXYZ Padang, walaupun sudah dimediasi oleh faktor motivasi kerja.

Secara empiris, hasil penelitian ini tidak didukung oleh hasil penelitian terdahulu, yang menunjukkan hasil bahwa lingkungan kerja seharusnya berpengaruh yang positif dan signifikan terhadap kinerja dan variable motivasi sebagai variable intervening (yayat hidayat, 2016). dan penelitian ini juga tidak sejalan dengan penelitian rayka dantyo et al. (2014) yang menyatakan bahwa berdasarkan hasil analisis menunjukkan bahwa motivasi kerja berstatus sebagai variabel moderator atau penguat dalam hubungan lingkungan kerja terhadap kinerja karyawan, karena nilai pengaruh tidak langsung lebih besar dari pengaruh langsung. Hal ini berarti lingkungan kerja akan mampu menaikkan kinerja karyawan lebih besar jika melalui peningkatan motivasi kerja.

Dari penelitian ini, maka dapat disimpulkan bahwa variabel lingkungan kerja yang dimediasi oleh motivasi kerja tidak mempengaruhi kinerja terhadap dokter spesialis kebidanan dan anak RSXYZ Padang. lingkungan kerja yang baik, dapat memotivasi karyawan dalam bekerja, semakin baik respon karyawan tentang lingkungan kerja, maka akan semakin meningkat pula kinerja karyawan. Dengan menciptakan suasana kerja yang baik di lingkungan instalasi kebidanan dan anak maka akan mendorong motivasi dokter spesialis untuk memberikan pelayanan yang baik sehingga hal ini secara tidak langsung dapat meningkatkan kinerja dokter spesialis tersebut. Peningkatan motivasi kerja dan kinerja dokter spesialis terhadap lingkungan kerja merupakan hal penting bagi pihak manajemen dalam peningkatan mutu dan kinerja pelayanan di RSXYZ Padang.

\section{Implikasi Penelitian}

Temuan dalam penelitian ini mempunyai implikasi penting bagi peningkatan kinerja dokter spesialis kebidanan dan anak RSXYZ Padang. Dimana Rumah Sakit harus memperhatikan penerapan remunerasi, motivasi kerja dan lingkungan kerja Karena hal tersebut dapat mempengaruhi terhadap peningkatan kinerja dokter spesialis dalam memberikan pelayanan yang baik.

Hal ini dapat dilihat dari hasil penelitian bahwa, remunerasi, motivasi kerja dan lingkungan kerja tidak berpengaruh dan signifikan terhadap kinerja dokter spesialis kebidanan dan anak RSXYZ Padang. Hal Ini menunjukkan bahwa penerapan remunerasi terhadap dokter spesialis kebidanan dan anak RSXYZ Padang harus lebih efektif, transparansi, akuntabel terhadap penilaian indikator kinerja individu (IKI) dokter spesialis. sebaiknya pihak manajemen melakukan pembaharuan terhadap sistem remunerasi di RS dengan sistem berbasis IT, sehingga dalam pengukuran IKI dokter spesialis sudah terkoneksi langsung dengan jumlah remunerasi yang diterima oleh dokter spesialis, sehingga dengan keterbukaan pembayaran remunerasi tersebut dapat meningkatkan motivasi kerja dokter spesialis dalam memberikan pelayanan paripurna. Dimana hal ini dapat di lihat dari teori remunerasi/ kompensasi adalah segala sesuatu yang diterima para karyawan sebagai balas jasa untuk hasil kerja mereka (Handoko,2003, p12), jadi melalui kompensasi tersebut karyawan dapat meningkatkan prestasi kerja, motivasi, kinerja serta meningkatkan kebutuhan hidupnya.

Dokter spesialis juga harus dapat meningkatkan motivasi kerja di instalasi 


\section{Terakreditasi Nasional}

\section{Available Online at: http://ejournal.upbatam.ac.id/index.php/jim}

kebidanan dan anak RSXYZ Padang agar kinerja yang diberikan terhadap pelayanan di rumah sakit terlaksana dengan optimal, hal ini dapat dilihat dari hasil penelitian bahwa motivasi kerja tidak berpengaruh dan signifikan terhadap kinerja. Pihak manajemen juga harus dapat terus meningkatkan motivasi kerja karyawan dengan memberlakukan kebijakan punishmen dan reward secara tegas, adil, dan transparan.

Sedangkan dari hasil penelitian menunjukkan variabel remunerasi berpengaruh terhadap motivasi kerja dokter spesialis kebidanan dan anak RSXYZ Padang, hal ini menunjukkan bahwa jika pihak manajemen menerapkan sistem pembayaran remunerasi dengan efektif, transparan dan akuntabel dapat meningkatkan motivasi kerja pada dokter spesialis kebidanan dan anak RSXYZ Padang.

Berdasarkan hasil telaah dokumen laporan Rincian Kewenangan Klinis (RKK) dokter spesialis kebidanan dan anak RSXYZ Padang pada tahun 2019 pada triwulan II mengalami peningkatan, bahwa sebelumnya laporan RKK tersebut menunjukkan hasil masih adanya dokter spesialis yang tidak melaksanakan pelayanan sesuai RKK. Namun setelah dilakukan monitoring dan evaluasi terkait laporan RKK tersebut dan pihak manajemen memberlakukan sistem punishmen yang tegas, sehingga dapat memotivasi dokter spesialis untuk melakukan kinerja pelayanan sesuai RKK. Berdasarkan teori motivasi oleh Fahmi (2013) mengemukakan bahwa motivasi kerja karyawan dapat dipengaruhi oleh faktor instrinsik dan ekstrinsik.

Hasil penelitian ini didukung dengan hasil wawancara mendalam dengan tim remunerasi di bagian SDM. Menurut tim remunerasi bahwa remunerasi yang diberikan saat ini sudah sesuai dengan standar dan panduan remunerasi yang ada di RSXYZ Padang. Remunerasi dinilai dari dari data IKI yang diserahkan oleh KSM perbulan, namun tim remun memvalidasi data tersebut berdasarkan laporan rawat jalan, rawat inap, karena beberapa dokter spesialis membuat IKI dengan poin yang tinggi, sedangkan setelah diverifikasi oleh tim remun berdasarkan, kehadiran, kepatuhan terhadap clinical pathway, kepatuhan jam visite dokter spesialis poin yang didapatkan tidak sesuai dengan IKI yang diserahkan oleh KSM. Remunerasi dokter spesialis dinilai berdasarkan poin IKI berdasarkan peniliaian kualitas dengan nilai poin 0,24 , kepatuhan 0,08 , keterlambatan $>75$ $\%$ dianggap tidak hadir, tidak melaksanakan wajib apel pagi, sehingga didapatkan hasil remunerasi; IKI = total capaian/ target yang ditetapkan X 100\%. Sehingga remunerasi yang didapatkan dokter spesialis berdasarkan total nilai tersebut, dan juga dipengaruhi oleh tingkat grading dokter spesialis.

\section{SIMPULAN}

Beberapa kesimpulan dari hasil penelitian ini dapat disampaikan sebagai berikut:

1. Hampir seluruh responden memiliki umur >35 tahun, dan jenis kelamin perempuan dengan status kepegawaian sebagai dokter PNS Kemenkes, dan merupakan dokter subspesialis di instalasi kebidanan dan anak RSXYZ Padang.

2. Remunerasi tidak memiliki pengaruh terhadap kinerja dokter spesialis di instalasi kebidanan dan anak RSXYZ Padang, mengindikasikan bahwa penerapan remunerasi belum membuat dokter spesialis merasa puas dengan sistem yang ada saat ini karena remunerasi yang efektif, transparan, dan akuntabel belum diterapkan pada dokter spesialis di instalasi kebidanan dan anak RSXYZ Padang.

3. Lingkungan kerja tidak memiliki pengaruh yang signifikan terhadap kinerja dokter spesialis di instalasi kebidanan dan anak RSXYZ Padang, mengindikasikan bahwa lingkungan kerja saat ini di instalasi kebidanan dan anak RSXYZ Padang belum mampu meningkatkan kinerja dokter spesialis.

4. Motivasi kerja tidak memiliki pengaruh terhadap kinerja dokter spesialis di instalasi kebidanan dan anak RSXYZ Padang, mengindikasikan bahwa motivasi kerja dokter spesialis saat ini belum dapat meningkatkan kinerja dokter spesialis di instalasi kebidanan dan anak RSXYZ Padang dalam memberikan pelayanan.

5. Remunerasi memiliki pengaruh yang positif terhadap motivasi kerja pada dokter spesialis kebidanan dan anak RSXYZ Padang, mengindikasikan 


\section{Terakreditasi Nasional}

Available Online at: http://ejournal.upbatam.ac.id/index.php/jim

penerapan remunerasi yang efektif, transparan, tepat waktu mempunyai peranan penting untuk meningkatkan motivasi kerja dokter spesialis kebidanan dan anak RSXYZ Padang dalam memberikan pelayanan.

6. Lingkungan kerja tidak memiliki pengaruh yang signifikan terhadap motivasi kerja pada dokter spesialis kebidanan dan anak RSXYZ Padang, mengindikasikan bahwa lingkungan kerja saat ini belum mempunyai peranan penting untuk meningkatkan motivasi kerja dokter spesialis kebidanan dan anak RSXYZ Padang dalam memberikan pelayanan.

7. Motivasi kerja belum terbukti sebagai variabel mediasi antara remunerasi dan kinerja pada dokter spesialis kebidanan dan anak RSXYZ Padang, mengindikasikan bahwa motivasi kerja tidak berpengaruh untuk meningkatkan kinerja yang baik terhadap pelayanan yang diberikan oleh dokter spesialis sehingga hal belum dapat meningkatkan kinerja dokter spesialis kebidanan dan anak RSXYZ Padang dalam memberikan pelayanan.

8. Motivasi kerja belum terbukti sebagai variabel mediasi antara lingkungan kerja dan kinerja pada dokter spesialis kebidanan dan anak RSXYZ Padang, mengindikasikan bahwa motivasi kerja tidak berpengaruh untuk meningkatkan kinerja yang baik terhadap pelayanan yang diberikan oleh dokter spesialis sehingga hal belum dapat meningkatkan kinerja dokter spesialis kebidanan dan anak RSXYZ Padang dalam memberikan pelayanan.

\section{DAFTAR PUSTAKA}

A.A. Anwar Prabu Mangkunegara.2012, Evaluasi Kinerja Sumber Daya Manusia PT. Reflika Aditama, Bandung.

Achmad Furqan, Muslimin Kara, Ahmad Jafar. 2015. Pengaruh Persepsi Remunerasi Terhadap Kinerja Pegawai Pada Kantor Pelayanan Pajak Pratama Makassar Utara.
Fakultas Ekonomi Bisnis Islam UIN Alauddin Makassar.

Andrianto, Findiana Galih. 2011. Pengaruh Remunerasi terhadap Motivasi Kerja Pegawai Studi Kasus Yayasan Pendidikan Telkom. Skripsi Sarjana pada Institut Manajemen Telkom Bandung: Tidak diterbitkan

Agung, Dwi, Perwitasari, Rifky Pratama. Faktor-Faktor Yang Mempengaruhi Remunerasi Direksi Studi Komporasi Perusahaan Di Australia, Singapura, Indonesia, Malaysia. Jurnal Akuntasi Dan Keuangan Indonesia. Vol. 13. 2016

Dian, A. 2018. Pengaruh Remunerasi, Lingkungan Kerja, dan Kompetensi Terhadap Kinerja Pegawai studi kasus pusat Pendidikan dan pelatihan pegawai kementerian Pendidikan dan kebudayaan. Skripsi Sarjana Pada UIN Syarif Hidayatullah Jakarta. 2018

Dina Kristina. 2015. Pengaruh Remunerasi Pegawai Terhadap Kinerja Pegawai Di Kementerian Secretariat Negara Republik Indonesia. Skripsi Fakultas Ilmu Social Dan Politik Universitas Agung Tirtayasa Serang.

Fahmi, Irhami. 2013. Manajemen Kepemimpinan. Bandung. ALFABETA,CV.

Ghozali, Imam. 2013. Aplikasi Analisis Program PLS Regresi denganProgram SmartPLS. Semarang: Badan Penerbit di UniversitasDiponegoro.

Gitosudarmo, lndriyo, 2000. Manajemen Sumberdaya Manusia. Gajahmada University Press. Yogyakarta.

Handoko, T. Hani.2011. Manajemen. Yogyakarta: Fakultas Ekonomi Universitas Gadjah Mada.

Hasibuan, Malayu. 2012. "Manajemen Sumber Daya manusia". Jakarta: PT Bumi Aksara

Hidayat Yayat. 2016. Pengaruh Sistem Remunerasi dan Lingkungan Kerja Terhadap Motivasi Kerja dan Dampaknya Terhadap Kinerja Perawat di RS Paru Dr. H.A Rotinsulu Bandung. Jurnal Administrasi Rumah Sakit. UNPAD 


\section{Terakreditasi Nasional}

Available Online at: http://ejournal.upbatam.ac.id/index.php/jim

Hidayat, Zainul, dkk. (2012), Pengaruh Lingkungan Kerja dan Disiplin Kerja Serta Motivasi Kerja Terhadap Kinerja Karyawan PDAM Kabupaten Lumajang. Jurnal WIGA, Vol. 2, No.1, Hal. 79-97

Khoiriyah, 2009. Pengaruh Lingkungan kerja Terhadap Kinerja Karyawan PT. Aji Bali Jayawijaya Surakarta

Iwan Dakota, Dumilah Ayuningtyas, Ratih Oktarina. 2017. Implementasi Kebijakan Remunerasi di Rumah Sakit Pemerintah. Vol.06, No.03, Hal 159160.

Keputusan Direktur Utama RSUP. Dr.M.Djamil Padang Nomor KP.01,04/I/317/2017 Tentang Pedoman Pelaksanaan Pemberian Remunerasi Kepada Pejabat, Pengelola, Dewan Pengawas, Dan Pegawai Di RSUP Dr.M.Djamil Padang.

Keputusan Menteri Keuangan Nomor 165/KMK.05/2008 tentang penetapan remunerasi bagi pejabat pengelola, dewan pengawas, dan pegawai BLU RSJPDHK. Jakarta: Kementerian Keuangan.

Marwansyah. 2010. "Manajemen Sumber Daya Manusia”. Bandung: Alfabeta

Mega Suryani. 2016. Pengaruh Motivasi Dan Remunerasi Terhadap Kinerja Pegawai Dengan Gaya Kepemimpinan Sebagai Variable Moderating Pada Kantor Wilayah Kementerian Hukum Dan Ham Lampung. Tesis Pascasarjan Fakultas Ekonomi Dan Bisnis Bandar Lampung.

Mintarsih Puji. 2017. Respon Organisasional Terhadap Implementasi Remunerasi Berbasis Kinerja Dalam Perspektif Resource Dependence Theory Dan New Institusional Sociology Studi Kasus Pada Badan Layanan Umum Poltekkes Kemenkes Malang. Tesis Fakultas Ilmu Ekonomi Dan Bisnis Universitas Brawijaya.

Peraturan Menteri Kesehatan Republik Indonesia Nomor 68 Tahun 2014 tentang Pedoman Penyusunan Sistem Remunerasi di Lingkungan Kementerian Kesehatan Yang Menerapkan Pola Pengelolaan Keuangan Badan Layanan Umum.
Peraturan Menteri Negara Pendayagunaan Aparatur Negara dan Reformasi Birokrasi Nomor 9 Tahun 2011, tentang pedoman penyusunan road mapreformasi birokrasi kementerian/lembaga dan pemerintah daerah

Peraturan Menteri Pendayagunaan Aparatur Negara Nomor 15 Tahun 2008 pedoman umum reformasi birokrasi.

Peraturan Menteri Sekretaris Negara RI Nomor 3 Tahun 2014 tentang Penegakkan Disiplin dalam Pelaksanaan Pemberian Tunjangan Kinerja Pegawai di Lingkungan Kementerian Sekretariat Negara RI.

Rayka Dantyo, Endang siti, Ika Ruhana. 2014. Pengaruh Lingkungan Kerja Terhadap Motivasi Kerja Dan Kinerja Karyawan Studi Kasus Pada Karyawan PT. AXA Financial Indonesia Cabang Malang. Jurnal Administrasi Bisnis. Vol. 14. 2014.

Sancoko, Bambang, (2010), Pengaruh Remunerasi terhadap Kualitas Pelayanan Publik, Jurnal IlmuAdministrasi dan Organisasi, Vol.17, No.1, Hal 43-51.

Sembiring, Masana. 2012. Budaya dan Kinerja Organisasi. Fokusmedia. Bandung.

Siregar NNE.Persepsi kepuasan karyawan terhadap efektivitas sistem remunerasi di RS Jantung dan Pembuluh Darah Harapan Kita tahun 2008-2010. [Tesis]. Depok: Fakultas Kesehatan Masyarakat Universitas Indonesia; 2011.

Sofyandi, Herman. 2013. "Manajemen Sumber Daya Manusia”.Yogyakarta: Graha Ilmu.

Sri Gusti Bima Harya Teja. 2017. Pengaruh Remunerasi Dan Motivasi Kerja Terhadap Kinerja Karyawan Studi Kasus Pada Kantor Pengawasan Dan Pelayanan Bea Cukai Surakarta. Jurnal Ekonomi Manajemen Sumber Daya. Vol. 19. 2017.

Sudarmanto. 2009. Kinerja dan Pengembangan Kompetensi SDM. Pustaka Pelajar: Yogyakarta.

Sulistiyani, Ambar Teguh., dan Rosidah. (2009). Manajemen Sumber Daya 
Available Online at: http://ejournal.upbatam.ac.id/index.php/jim

Manusia Edisi Pertama. Yogyakarta:

Graha Ilmu.

Sugioyono. 2013. Metode Penelitian

Kuantitatif, Kualitatif dan $R \& D$.

Bandung: Alfabeta.

Sucianto.2016. Pengaruh Remunerasi,

Motivasi Kerja, Dan Stress Kerja,

Terhadap Kepuasaan Kerja Dan

Kinerja Pegawai. Tesis Magister

Akuntasi Fakultas Ekonomi Dan Bisnis

Univeristas Sebelas Maret Surakarta.). 